\title{
А.Н. Мацынин
}

ГОО ВПО «Донецкий национальный медицинский университет имени М. Горького», Донецк

\section{МОРФОЛОГИЧЕСКОЕ ОБОСНОВАНИЕ ПРЕДГРАВИДАРНОЙ ЙОДНОЙ ПРОФИЛАКТИКИ}

Одной из актуальных медико-социальных проблем на современном этапе остается борьба с йодным дефицитом [1]. Особое значение данная проблема приобретает, когда речь идет о беременности. Связано это прежде всего с возможными гестационными и перинатальными осложнениями, вызванными йодным дефицитом [2]. Несмотря на многократные попытки медицинского сообщества привлечь внимание к проблеме профилактики йодного дефицита, она далека от решения, и не только в Донецком регионе, но и на территории Украины и России [3]. К сожалению, не существует государственной программы йодной профилактики, которая бы обеспечила адекватный уровень йодного потребления населением и особенно беременными в регионе природного йодного дефицита, которым и является Донецкая область [4]. В то же время, несмотря на имеющиеся строгие рекомендации по профилактике йодного дефицита у беременных, проблема все еще далека от разрешения.

Целью настоящей работы стало морфологическое обоснование предгравидарной йодной профилактики для женщин, проживающих в регионе природного йодного дефицита.

\section{МАТЕРИАЛ И МЕТОДЫ}

Для достижения поставленной цели было проведено органометрическое исследование последов родильниц, проживающих в Донецкой области. Основную группу составили 41 послед родильниц с йодным дефицитом, выявленным в первом триместре гестации. В дальнейшем йодную профилактику йодидом калия в дозе 250 мкг в сутки родильницы получали с 6-10 недель гестации. Группу сравнения составили 59 последов родильниц, получавших йодную профилактику йодидом калия - 200 мкг в сутки на протяжении 4-6 месяцев предгравидарного периода, а с наступлением гестации доза йодида калия была увеличена до рекомендуемой - 250 мкг в сутки [5].
Формат представления данных для количественных показателей - среднее \pm ошибка среднего; для качественных показателей - частота в $\% \pm$ ошибка репрезентативности. Для сравнения средних величин с нормальным распределением (тест Шапиро-Уилка) использовали критерий Стьюдента (t-тест для независимых выборок) в программе «Статистика 6.5». Для сравнения частот применяли многофункциональный критерий Фишера (угловое преобразование). Нулевую гипотезу отвергали при $\mathrm{p}<0,05$.

\section{РЕЗУЛЬТАТЫ И ОБСУЖДЕНИЕ}

В представленной таблице указаны основные органометрические особенности последов родильниц основной группы и группы сравнения. В последах родильниц с исходным йодным дефицитом (основная группа) в 4,3 раза чаще ( $\mathrm{p}<0,05)$, в сравнении с последами родильниц с нормальным уровнем йодного потребления (группа сравнения), регистрировались аномальные формы плаценты (в виде неправильного диска), встречавшиеся в 29,3 $\pm 7,1 \%(12)$ и $6,8 \pm 3,3 \%(4)$ случая соответственно. Частота формирования добавочной дольки плаценты у родильниц основной группы не отличалась $(\mathrm{p}>0,05)$ от ее частоты в группе сравнения и составила $2,4 \pm 2,4 \%(1)$ и $1,7 \pm 1,7 \%(1)$ случая соответственно.

Аномалии прикрепления пуповины (парацентральное или краевое) в последах родильниц основной группы встречались статистически значимо чаще ( $<<0,05)$, чем в группе сравнения. В основной группе данные аномалии отмечены в $26,8 \pm 6,9 \%(11)$ случая, что в 3,2 раза чаще, чем в группе сравнения, где данная аномалия отмечена в $8,5 \pm 3,6 \%(5)$ случая.

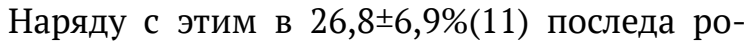
дильниц основной группы была зарегистрирована различная патология пуповины, что отли-

(C) А.Н. Мацынин, 2020

(c) Университетская Клиника, 2020 
Органометрические особенности последов обследованных родильниц

\begin{tabular}{|c|c|c|}
\hline \multirow{2}{*}{ Показатель } & \multicolumn{2}{|c|}{ Группа } \\
\hline & $\begin{array}{c}\text { Основная, } \\
n=41\end{array}$ & $\begin{array}{c}\text { Сравнения, } \\
n=59\end{array}$ \\
\hline Маса плаценты, г (Mm) & $490,7 \pm 28,9$ & $497,4 \pm 24,6$ \\
\hline Толщина плаценты, мм (Mm) & $22,2 \pm 2,1$ & $22,3 \pm 1,7$ \\
\hline Диаметр плаценты, см (Mm) & $20,1 \pm 1,2$ & $19,4 \pm 1,3$ \\
\hline Плацентарно-плодовый индекс (Mm) & $0,14 \pm 0,06$ & $0,14 \pm 0,07$ \\
\hline Добавочная долька плаценты (Pm\%(n)) & $2,4 \pm 2,4(1)$ & $1,7 \pm 1,7(1)$ \\
\hline Аномалия формы плаценты (Pm\%(n)) & $29,3 \pm 7,1(12) *$ & $6,8 \pm 3,3(4)$ \\
\hline Аномалия прикрепления пуповины (Pะm\%(n)) & $26,8 \pm 6,9(11) *$ & $8,5 \pm 3,6 \%(5)$ \\
\hline $\begin{array}{l}\text { Патология пуповины }(\mathrm{P} \pm \mathrm{m} \%(\mathrm{n})) \text { в т.ч.: } \\
\text { - ложный узел } \\
\text { - патологическая извитость }\end{array}$ & $\begin{array}{c}26,8 \pm 6,9(11)^{*} \\
4,9 \pm 3,4(2) \\
22,0 \pm 6,5(9) *\end{array}$ & $\begin{array}{c}5,1 \pm 2,9(3) \\
- \\
5,1 \pm 2,9(3)\end{array}$ \\
\hline
\end{tabular}

Примечание: * - различия между группами статистически значимы, p<0,05

чало их от последов группы сравнения, где такие изменения регистрировались в $5,1 \pm 2,9 \%$ (3) случая, $\mathrm{p}<0,05$. Следовательно, частота патологии пуповины у родильниц основной группы в 5,3 раза превышала ее частоту в группе сравнения. Наиболее частой патологией пуповины была патологическая извитость ее сосудов, которая регистрировалась в последах родильниц основной группы в 4,3 раза чаще, чем в последах родиль-

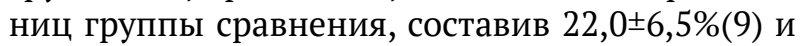
$5,1 \pm 2,9 \%(3)$ случая соответственно, $\mathrm{p}<0,05$.

Кроме того, в последах родильниц основной

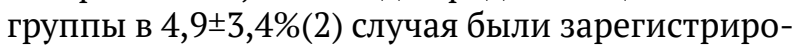
ваны истинные узлы пуповины, которые не регистрировались в последах группы сравнения.

Наряду с этим при органометрическом анализе не было установлено различий $(p>0,05)$ между основной группой и группой сравнения показателей массы плацент, их толщины и диаметра. Так, масса плацент, их толщина и диаметр

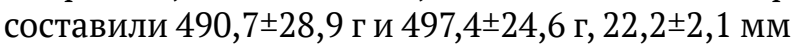
и $22,3 \pm 1,7$ мм и $20,1 \pm 1,2$ см и $19,4 \pm 1,3$ см соответственно в основной группе и группе сравнения. Таким образом, было установлено что плацентарно-плодовый индекс в сравниваемых группах не имел статистически значимой разницы ( $>>0,05)$ и составил $0,14 \pm 0,06$ и $0,14 \pm 0,07$ соответственно в основной группе и группе сравнения. Это может свидетельствовать в пользу адекватности, проводимой во II и III периоде гестации йодной профилактики.

\section{В Ы В 0 д Ы}

Таким образом, выявленные органометрические особенности последов родильниц с исходным йодным дефицитом (основная группа) и их отличие от последов родильниц без йодного дефицита (группа сравнения) на начало гестационного периода могут свидетельствовать о нарушении процессов формирования и развития плаценты и пуповины в первые дни и недели гестации.

В последах родильниц с исходным йодным дефицитом в 4,3 раза чаще, в сравнении с последами родильниц с нормальным уровнем йодного потребления, регистрировались аномальные формы плаценты. Кроме того, в 3,2 раза чаще регистрировались аномалии прикрепления пуповины и в 5,3 раз чаще - аномалии ее развития.

Можно утверждать, что данные процессы обусловлены недостатком йода в организме беременных в этот период гестации, что вызвано проживанием в регионе природного йодного дефицита и отсутствием предгравидарной йодной профилактики.

Следует продолжить исследования плацентарного комплекса у беременных с исходным йодным дефицитом для установления взаимосвязи дефицита йода с гестационными и перинатальными осложнениями, а также разработку комплекса мер профилактики и лечения данных осложнений у жительниц региона природного йодного дефицита. 


\section{А.Н. Мацынин}

ГОО ВПО «Донецкий национальный медицинский университет имени М. Горького», Донецк

\section{МОРФОЛОГИЧЕСКОЕ ОБОСНОВАНИЕ ПРЕДГРАВИДАРНОЙ ЙОДНОЙ ПРОФИЛАКТИКИ}

Целью настоящей работы стало морфологическое обоснование предгравидарной йодной профилактики для женщин, проживающих в регионе природного йодного дефицита.

Материал и методы. Проведено органометрическое исследование последов родильниц, проживающих в регионе природного йодного дефицита - Донецкой области. Основная группа - 41 послед родильниц с йодным дефицитом в I триместре гестации. В последующем йодную профилактику йодидом калия в дозе 250 мкг в сутки данные родильницы получали с 6 - 10 недель гестации. Группа сравнения - 59 последов родильниц, получавших йодную профилактику йодидом калия - 200 мкг в сутки на протяжении 4 - 6 месяцев предгравидарного периода, а с наступлением гестации - 250 мкг в сутки.

Результаты и их обсуждение. В последах родильниц с исходным йодным дефицитом (основная группа) в 4,3 раза чаще $(\mathrm{p}<0,05)$, в сравнении с последами родильниц с нормальным уровнем йодного потребления (группа сравнения), регистрировались аномальные формы плаценты (в виде неправильного диска), встречавшиеся в $29,3 \pm 7,1 \%(12)$ и $6,8 \pm 3,3 \%(4)$ случая соответственно. Формирование добавочной дольки плаценты зарегистрировано у родильниц основной группы в $2,4 \pm 2,4 \%(1)$ случая, в группе сравнения - в $1,7 \pm 1,7 \%(1)$ случая, $p>0,05$. Аномалии прикрепления пуповины (парацентральное или краевое) в последах родильниц основной группы встречались статистически чаще $(\mathrm{p}<0,05)$, чем в группе сравнения. В основной группе данные аномалии отмечены в $26,8 \pm 6,9 \%$
(11) случая, что в 3,2 раза чаще, чем в группе сравне-

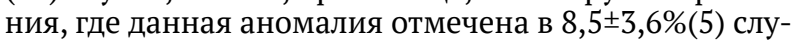
чая. Частота патологии пуповины у родильниц основной группы в 5,3 раза превышала ее частоту в группе сравнения и составила $26,8 \pm 6,9 \%(11)$ и $5,1 \pm 2,9 \%(3)$ случая соответственно, $\mathrm{p}<0,05$. Патологическая извитость сосудов пуповины регистрировалась в последах родильниц основной группы в $22,0 \pm 6,5 \%(9)$ случая и была в 4,3 раза чаще, чем в последах группы сравнения, $-5,1 \pm 2,9 \%$ (3) случая, $\mathrm{p}<0,05$. Истинные узлы пуповины, не встречаясь в группе сравнения, регистрировались в основной группе в $4,9 \pm 3,4 \%(2)$ случая. Не было установлено различий (р>0,05) массы плацент, их толщины и диаметра между основной группой и группой сравнения, где они составили $490,7 \pm 28,9$ г и $497,4 \pm 24,6$ г, 22,2 $\pm 2,1$ мм и $22,3 \pm 1,7$ мм и $20,1 \pm 1,2$ см и $19,4 \pm 1,3$ см соответственно. Плацентарно-плодовый индекс в сравниваемых группах не имел отличий $(p>0,05)$ и составил $0,14 \pm 0,06$ и $0,14 \pm 0,07$ соответственно в основной группе и группе сравнения.

Выводы. Выявленные органометрические отличительные особенности последов родильниц основной группы могут свидетельствовать о нарушении процессов формирования и развития плаценты и пуповины в первые дни и недели гестации, обусловленные йодным дефицитом в I триместре гестации, который вызван проживанием в регионе природного йодного дефицита и отсутствием предгравидарной йодной профилактики.

Ключевые слова: йодный дефицит, прегравидарная йодная профилактика, плацента, пуповина.

\section{A.N. Matsynin}

SEI HPE «M. Gorky Donetsk National Medical University», Donetsk

\section{MORPHOLOGICAL SUBSTANTIATION OF PREGRAVID IODINE PROPHYLAXIS}

The aim of this work was the morphological substantiation of pregravid iodine prophylaxis for women living in the region of natural iodine deficiency.

Material and methods. An organometric study of the secundineses of puerperas, living in the region of natural iodine deficiency - the Donetsk region. The main group - 41 secundineses of puerperas with iodine deficiency in the first trimester of gestation. Subsequently iodine prophylaxis with potassium iodide at a dose of $250 \mathrm{mcg}$ per day was given to these puerperas from 6 to 10 weeks of gestation. The comparison group consisted of $59 \mathrm{se}-$ cundineses of puerperas who received iodine prophylaxis with potassium iodide 200 mcg per day for 4-6 months of the pregravid period, and with gestation onset -250 mcg per day.

Results and their discussion. Abnormal forms of the placenta (in the form of an irregular disk) were found in the placenta of the puerperas of the main group 4,3 times more often $(p<0,05)$, in comparison with the secundineses of the puerperas of the comparison group, found in $29,3 \pm 7,1 \%$ (12) and $6,8 \pm 3,3 \%$ (4) cases, respectively. The formation of an additional placental lobule was record- ed in puerperas of the main group in $2,4 \pm 2,4 \%$ (1) cases, in the comparison group $-1,7 \pm 1,7 \%$ (1) cases, $p>0,05$. Anomalies in the attachment of the umbilical cord in the secundineses of the puerperas of the main group were met statistically more often $(p<0,05)$ than in the comparison group. In the main group, these anomalies were noted in $26,8 \pm 6,9 \%$ (11) cases, which is 3,2 times more likely than in the comparison group, where this anomaly was noted in $8,5 \pm 3,6 \%$ (5) cases. The frequency of umbilical cord pathology in puerperas of the main group was 5,3 times higher than its frequency in the comparison group and amounted to $26,8 \pm 6,9 \%$ (11) and $5,1 \pm 2,9 \%$ (3) cases, respectively, $p<0,05$. Pathological tortuosity of the vessels of the umbilical cord was recorded in the secundineses of the puerperas of the main group in $22,0 \pm 6,5 \%$ (9) cases and was 4,3 times more often than in the secundineses of the comparison group $-5,1 \pm 2,9 \%$ (3) cases, $p<0,05$. True umbilical cord knots, that were not met in the comparison group, were recorded in the main group in $4,9 \pm 3,4 \%$ (2) cases. No differences were found $(p>0,05)$ of placenta mass, their thickness and diameter between the main group and the comparison group, where they 
amounted to $490,7 \pm 28,9$ g. and $497,4 \pm 24,6$ g., $22,2 \pm 2,1$ $\mathrm{mm}$ and $22,3 \pm 1,7 \mathrm{~mm}$ and $20,1 \pm 1,2 \mathrm{~cm}$ and $19,4 \pm 1,3 \mathrm{~cm}$, respectively. The placental-fetal index in the compared groups did not differ $(p>0,05)$ and amounted to $0,14 \pm 0,06$ and $0,14 \pm 0,07$, respectively, in the main group and the comparison group.

Findings. The revealed distinctive features of the secundineses of the puerperas of the main group may in- dicate an abnormality of the processes of formation and development of the placenta and umbilical cord in the first days and weeks of gestation, due to iodine deficiency in the first trimester of gestation, which is caused by the presence of natural iodine deficiency in the region and the absence of pregravid iodine prophylaxis.

Key words: iodine deficiency, pregravid iodine prophylaxis, placenta, umbilical cord.

\section{ЛИТЕРАТУРА}

1 Zimmermann MB, Jooste PL, Pandav CS. Iodine-deficiency disorders. Lancet. 2008; 372 (9645): 1251-1262. doi: 10.1016/s0140-6736(08)61005-3

2. Крюков Н.Н., Жукова В.В., Самыкина Л.Н., Самыкина Е.В., Мирзонов В.А., Зимина С.В. Гормональные взаимоотношения при беременности в условиях йодного дефицита. Известия Самарского научного центра Российской академии наук. 2011; Т. 13, 1 (7): 1612-1615.

3. Трошина Е.А., Платонова Н.М., Панфилова Е.А., Панфилов К.О. Аналитический обзор по результатам мониторинга основных эпидемиологических характеристик йододефицитных заболеваний у населения Российской Федерации за период 2009-2015 гг. Проблемы эндокринологии. 2018; Т. 64, 1: 21-37. doi: 10.14341/ probl9308

4. Мацынин А.Н. Уровень потребления йода беременными Донбасса.Репродуктивное здоровьеженщины.2008; 3(37): $10-11$.

5. World Health Organization, UNICEF, International Council for Control of Iodine Deficiency Disorders. Assessment of iodine deficiency disorders and monitoring their elimination: a guide for programme managers. Geneva: World Health Organization; 2007.

6. Зосимов А.Н., Пархоменко Л.К. Доказательное рецензирование медицинских диссертаций. Харьков: Факт; 2008. 150 .

\section{REFERENCES}

1 Zimmermann MB, Jooste PL, Pandav CS. Iodine-deficiency disorders. Lancet. 2008; 372 (9645): 1251-1262. doi: 10.1016/s0140-6736(08)61005-3

2. Kryukov N.N., Zhukova V.V., Samykina L.N., Samykina E.V., Mirzonov V.A., Zimina S.V. Gormonal'nye vzaimootnosheniya pri beremennosti $\mathrm{v}$ usloviyakh iodnogo defitsita. Izvestiya Samarskogo nauchnogo tsentra Rossiiskoi akademii nauk. 2011; , T. 13, 1 (7): 1612-1615 (in Russian).

3. Troshina E.A., Platonova N.M., Panfilova E.A., Panfilov K.O. Analiticheskii obzor po rezul'tatam monitoringa osnovnykh epidemiologicheskikh kharakteristik iododefitsitnykh zabolevanii u naseleniya Rossiiskoi Federatsii za period 2009-2015 gg. Problemy endokrinologii. 2018; T. 64, 1: 21-37 (in Russian). doi: 10.14341/probl9308

4. Matsynin A.N. Uroven' potrebleniya ioda beremennymi Donbassa. Reproduktivnoe zdorov'e zhenshchiny. 2008; 3 (37): 10 -11 (in Russian).

5. World Health Organization, UNICEF, International Council for Control of Iodine Deficiency Disorders. Assessment of iodine deficiency disorders and monitoring their elimination: a guide for programme managers. Geneva: World Health Organization; 2007.

6. Zosimov A.N., Parkhomenko L.K. Dokazatel'noe retsenzirovanie meditsinskikh dissertatsii. Khar'kov: Fakt; 2008. 150 (in Russian). 